(C) Пушко О.О., Литвиненко Н.В.

UDC 616.831-005.1-085:615.21

DOI https://doi.org/10.31718/mep.2021.25.3-4.02

\title{
ЗАСТОСУВАННЯ А-ГЛІЦЕРИЛФОСФОРИЛХОЛІНУ В СХЕМІ КОМПЛЕКСНОГО ЛІКУВАННЯ ДЛЯ ФУНКЦІОНАЛЬНОГО ВІДНОВЛЕННЯ ПІСЛЯ МОЗКОВОГО ПІВКУЛЬОВОГО ІШЕМІЧНОГО ІНСУЛЬТУ
}

Пушко О.О., Литвиненко Н.В.

Poltava State Medical University, Poltava, Ukraine

Дослідження є фрагментом науково-дослідної роботи Полтавського державного медичного університету «Вплив комплексної фрізичної (медичноі) реабілітації на моторні, когнітивні й психоемоційні порушення при гострій цереброваскулярній патології: оптимізація діагностики, прогнозування та лікування з обгрунтуванням диференційованого підходу» (номер державної реєстрації 0120U105395).

Abstract. The article considers the influence of a-glycerylphosphorylcholine in the scheme of comprehensive therapy on the dynamics of functional recovery in patients with cerebral hemispheric ischemic stroke. Against the background of the progressive growth of acute cerebral infarction, the problem of timely care is relevant. Timely treatment of stroke, based on evidence-based medicine, along with early activation and rehabilitation of patients is designed to reduce mortality and subsequent disability of patients. Given that cholinergic insufficiency and structural and functional damage of neurons play an important role in the pathogenesis of post-stroke disorders, the use of medicines for their correction, in particular a-glycerylphosphorylcholine, is justified. Choline alfoscerate, a precursor of acetylcholine and phosphatidylcholine, is broken down by enzymes into choline and glycerophosphate when ingested, and the choline thus obtained is able to improve neuronal functionality in patients with neurodegenerative and vascular diseases. The study revealed a significantly better recovery of impaired motor and cognitive functions after cerebral hemispheric stroke under the influence of comprehensive therapeutic and rehabilitation measures using active rehabilitation methods in conjunction with aglycerylphosphorylcholine. The results obtained during the study allow us to report the advantage of a combination of methods of active rehabilitation and the use of the pharmacological agent a-glycerylphosphorylcholine. The feasibility and efficacy of a-glycerylphosphorylcholine are related to its ability to reduce motor and cognitive deficits after ischemic stroke. The scheme of comprehensive treatment of patients in acute and restorative periods of cerebral hemispheric ischemic stroke with the use of a-glycerylphosphorylcholine helps to increase the effectiveness of functional recovery after an acute cerebral accident, and can be used in the use of therapeutic and rehabilitation programs for patients after cerebral hemispheric ischemic stroke to reduce the post-stroke deficit.

Key words: ischemic stroke, post-stroke deficit, motor disorders, cognitive disorders, psychoemotional disorders, aglycerylphosphorylcholine, functional recovery, neurorehabilitation.

У статті розглянуто вплив а-гліцерилфосфорилхоліну в схемі комплексної терапії на динаміку функціонального відновлення порушень у пацієнтів із мозковим півкульовим ішемічним інсультом. На тлі прогресуючого росту гострого інфаркту мозку зазнає актуалізації проблема вчасного надання допомоги при ньому. Своєчасне лікування інсульту, побудоване на засадах доказової медицини, поряд з ранньою активацією та реабілітацією пацієнтів покликане знизити смертність та подальшу інвалідизацію пацієнтів. 3 огляду на те, що в патогенезі постінсультних порушень важливу роль відіграють холінергічна недостатність і структурно-функціональні пошкодження нейронів, виправданим $\epsilon$ використання лікарських засобів, спрямованих на їх корекцію, зокрема препаратів а-гліцерилфосфорилхоліну. Холін альфосцерат, виступаючи попередником ацетилхоліну та фосфатидилхоліну, під дією ферментів при потраплянні в організм розщеплюється на холін і гліцерофосфат, а отриманий таким чином холін здатний покращувати нейронну функціональність у пацієнтів із нейродегенеративними та судинними захворюваннями. У процесі дослідження виявлено достовірно краще відновлення порушених моторно-когнітивних функцій після мозкового півкульового ішемічного інсульту під впливом комплексних терапевтично-реабілітаційних заходів із застосуванням методів активної реабілітації спільно з препаратом а-гліцерилфосфорилхоліну. Отримані у ході дослідження результати, дають змогу констатувати перевагу комбінації методів активної реабілітації та використання фармакологічного препарату а-гліцерилфосфорилхоліну. Доцільність і ефективність застосування а-гліцерилфосфорилхоліну для зменшення моторно-когнітивного дефіциту після ішемічного інсульту пов'язане з його здатністю до зменшення моторнокогнітивного дефіциту після ішемічного інсульту. Схема комплексного лікування пацієнтів у гострому та відновному періодах мозкового півкульового ішемічного інсульту з застосуванням а-гліцерилфосфорилхоліну сприяє підвищенню ефективності функціонального відновлення після гострої церебральної катастрофи, може отримати практичне застосування у застосуванні терапевтично-реабілітаційних програм для пацієнтів після перенесеного мозкового півкульового ішемічного інсульту для зменшення постінсультного дефіциту.

Ключові слова: ішемічний інсульт, постінсультний дефріцит, моторні порушення, когнітивні порушення, психоемоційні порушення, а-гліцерилфосфорилхолін, функціональне відновлення, нейрореабілітація.

*Цитування при атестації кадрів: Пушко О.В., Литвиненко Н.В. N. V. Застосування а-гліцерилфосфрорилхоліну в схемі комплексного лікування для Функціонального відновлення після мозкового півкульового ішемічного інсульту // Проблеми екології $і$ медицини. - 2021. - T. 25, № 3-4. - С. 8-13. 


\section{Вступ}

Гострий інфаркт мозку, як і вчасне надання допомоги при ньому, - надзвичайно актуальна проблема, адже щохвилини після гострої ішемії мозок втрачає 1,9 млн нейронів та 14 млрд синапсів, що свідчить про наявність прогресуючого порушення мозкових фрункцій. Актуальність проблеми зумовлена прогресуючим ростом частоти даної патології. В усьому світі мозкові інсульти є однією з провідних причин смертності й інвалідизації населення, створюючи серйозне навантаження на системи охорони здоров'я, економіки й населення в цілому $[1,2]$.

Патоморфологічним субстратом ішемічного інсульту $є$ інфаркт мозку, що являє собою зону некрозу, яка утворюється внаслідок грубих порушень метаболізму тканини мозку, зумовлених гострою фокальною церебральною ішемією. Центральна зона, або ядро інфаркту виникає через 6-8 хвилин після гострої фокальної ішемії, а протягом кількох годин навколо ядра інфраркту формується зона пенумбри, або «ішемічної півтіні», період якої має вкрай стислі часові межі й становить "терапевтичне вікно» (перші 4,5 години від початку церебрального інфаркту). Основними складовими клінічної картини інсульту $€$ моторні, сенсорні, афратичні, психічно-когнітивні порушення [2-5].

Для науково обґрунтованих рекомендацій щодо ведення пацієнтів після інсульту доцільно послуговуватися термінами «нейропластичність», що властива нервовій системі, «нейропротекція», що вкрай важлива в найгострішому й гострому періодах інсульту та в подальшому «нейрорепарація» як фаза нейрогенезу. Патогенетичними механізмами розвитку постінсультних моторно-нейрокогнітивних порушень $€$ загибель нейронів у зоні вогнища із вторинною нейродегенерацією, ушкодження аксональних трактів, порушення кортикальних зв'язків, також велике значення мають гіпоперфузія мозку, ендотеліальна дисфункція, хронічне запалення, церебральна гіпотрофія. Ендогенна захисна активність, яка керує фрундаментальними нейробіологічними процесами, має додатково посилюватися фрармакологічними втручаннями, фрізичною активністю, психологічною підтримкою, стимуляцією 3 боку зовнішнього середовища і будь-якою комбінацією перерахованих фракторів, направлених на реабілітацію пацієнтів, здатних поліпшити їх стан після інсульту $[6,7]$.

Лікування інсульту має бути своєчасним та базуватися на засадах доказової медицини, що допоможе знизити смертність та подальшу інвалідизацію пацієнтів, а рання активація й реабілітація осіб із інсультом має починатися якомога раніше, з перших діб перебування пацієнта в інсультному відділенні, відразу після стабілізації основних вітальних функцій (дихання й гемодинаміки) [3, 8].

За даними світової літератури, рання активація після інсульту та якомога раніший початок реабілітаційних заходів знижує ризик повторних інсультів та покращує функціональний вихід, а оскільки в патогенезі постінсультних порушень важливу роль відіграють холінергічна недостатність і структурно-функціональні пошкодження нейронів, доцільним є додаткове застосування лікарських засобів, спрямованих на їх корекцію, зокрема препаратів а-гліцерилфосфорилхоліну [2, 9-12].

Механізм дії а-гліцерилфосфрорилхоліну (а-GPC) заснований на тому, що холін альфосцерат $є$ попередником ацетилхоліну та фосфатидилхоліну й при по- траплянні в організм під дією фрерментів розщеплюється на холін і гліцерофоссрат. Унаслідок підвищення концентрації отриманого таким чином холіну в плазмі крові та його електронейтральності він здатний проникати крізь гематоенцефалічний бар'єр і брати участь у синтезі ацетилхоліну та фросфоліпідів безпосередньо в головному мозку, що призводить до підвищення холінергічної активності внаслідок стимуляції синтезу ацетилхоліну та його вивільнення, а також біодоступності ацетилхоліну в нервових структурах i сповільнення розвитку вікових мікроструктурних змін мозку, що покращує нейронну функціональність у пацієнтів із нейродегенеративними та судинними захворюваннями [13-17].

Встановлено, що а-GPC збільшує вміст ацетилхоліну в головному мозку, покращує стан нейронних мембран, посилює церебральні метаболічні процеси, чинить нейропротективний вплив на центральну нервову систему, позитивно вливаючи на процеси нейропластичності [18-20].

Метою роботи була оцінка впливу а-GPC в схемі комплексної терапії на динаміку функціонального відновлення порушень у пацієнтів із мозковим півкульовим ішемічним інсультом (МПII), дослідження кореляційних зв'язків між показниками моторно-когнітивних порушень.

\section{Матеріали і методи дослідження}

У дослідженні взяли участь 90 пацієнтів: 30 практично здорових осіб (контрольна група, КГ, n=30) без перенесених гострих порушень мозкового кровообігу (анамнестично й нейровізуалізаційно), із яких $53,3 \%$ чоловіків $(n=16)$ та $46,7 \%$ жінок $(n=14)$, середній вік пацієнтів у групі становив $57,9 \pm 1,45$ років та 60 пацієнтів із діагнозом МПII $(n=60)$, із яких $61,7 \%$ чоловіків $(n=37)$ та $38,3 \%$ жінок $(n=23)$, середній вік пацієнтів у

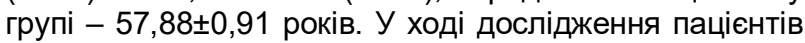
із МПІІ було розділено на дві групи: перша - група 1

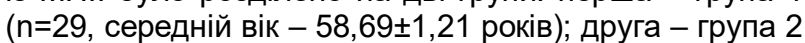
$(\mathrm{n}=31$, середній вік $-57,13 \pm 1,35$ років). Період спостереження - півроку. Тестування проводилося на 3-7 день (візит 1, V1), 30-й день (візит 2, V2), 90-й день (візит 3, V3), 180-й день (візит 4, V4) МПII. У лікуванні пацієнтів обох груп застосовувалися заходи із використанням терапії відповідно до чинного клінічного протоколу медичної допомоги пацієнтам із ішемічним інсультом (Наказ Міністерства охорони здоров'я України №602 від 03.08.2012) у поєднанні з двома курсами реабілітаційного лікування із використанням методів активної реабілітації після першого та після третього оглядів (заняття з фрізичним терапевтом 2 години щодня впродовж 21 дня). Додатково в схемі комплексного лікування пацієнти групи 2 отримували два курси препарату а-гліцерилфосфорилхоліну після першого та після третього оглядів по 1000 мг на добу впродовж 28 днів: 7 днів внутрішньовенно краплинно та ще 21 день внутрішньом'язово.

Функціональне відновлення оцінювали із застосуванням валідних шкал, зокрема: для оцінки моторних порушень використовували National Institutes of Health Stroke Scale (NIHSS), Barthel Activities of Daily Living Index (ADL BI), Modified Rankin Scale (mRS), Berg Balance Scale (BBS), для оцінки когнітивної сорери використовували Mini Mental State Examination (MMSE), Montreal Cognitive Assessment (MoCa) [2, 3, 9]. 
За результатами NIHSS: до 5 балів оцінювали як легкий інсульт, 6-13 балів - інсульт середньої тяжкості, 14-20 балів - тяжкий інсульт, більше 20 балів - дуже тяжкий інсульт. Оцінка за ADL BI: до 49 балів відповідає тяжкій інвалідності й залежності від сторонньої допомоги, 50-74 бали свідчать про помірну інвалідність, 75-100 балів відповідає мінімальному обмеженню або відновленню втрачених неврологічних функцій. Оцінка за mRS: 0 балів свідчить про відсутність симптомів; 1 бал - відсутність суттєвої функціональної неспроможності, здатність до виконання повсякденних обов'язків і буденної активності, незважаючи на наявність симптомів; 2 бали - легке порушення функціональної спроможності, нездатність до минулої активності, але збережена здатність до обслуговування власних потреб без сторонньої допомоги; 3 бали - помірне порушення функціональної спроможності, необхідність деякої сторонньої допомоги, збережена здатність ходити без сторонньої допомоги; 4 бали - помірно-тяжке порушення функціональної спроможності, нездатність ходити без сторонньої допомоги і самостійно задовольняти фізіологічні потреби; 5 балів - важка функціональна неспроможність, «прикутість» до ліжка, нетримання сечі та калу, потреба в постійному нагляді та увазі. За результатами MMSE 28-30 балів оцінювали як відсутність когнітивних порушень (КП), 24-27 балів - прекогнітивні порушення (преКП), 20-23 балів - легкі когнітивні порушення, 11-19 балів помірні когнітивні порушення. За МоСа менше 26 балів оцінювали як прояви когнітивних порушень. При огляді на 3-7 день після МПII, пацієнти з балом за NIHSS більше 20 балів, за mRS - 0 і 5 балів, за MMSE 10 і менше балів у дослідження не включалися.

Дослідження проводилося на базі Комунального підприємства «Полтавська обласна клінічна лікарня ім. М. В. Скліфосовського Полтавської обласної ради», Комунального підприємства «1-а міська клінічна лікарня Полтавської міської ради» та Центру неврології і реабілітації «Lytvynenko Clinic» (м. Полтава).

Статистична обробка отриманих даних проведена 3 використанням прикладних програм «Excel», «SPSS», «Statistica 6.0», застосуванням методів описової статистики та статистичного аналізу. Зокрема, описова статистика представлена у вигляді середньо-

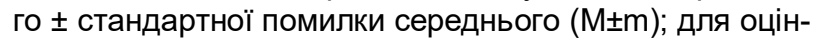
ки міжгрупових відмінностей використовували U-тест за методом Манна-Уїтні (Mann-Whitney U-test). Для оцінки динамічних змін усередині груп застосовували непараметричний тест Вілкоксона (Wilcoxon) для парних величин. Кореляційний зв'язок між кількісними показниками оцінювали за допомогою коефіцієнту рангової кореляції Спірмена (Spearman). Для оцінки взаємозв'язків між якісними показниками використовували критерій $\chi^{2}$ за Пірсоном (Pearson). Відмінності вважали статистично значимими при $p<0,05$.

У ході дослідження у всіх пацієнтів було отримано інформовану згоду на участь у дослідженні та були дотримані Правила гуманного ставлення до пацієнтів згідно з вимогами Токійської декларації Всесвітньої медичної асамблеї, вимоги Міжнародних рекомендацій Гельсінської декларації прав людини, «Конвенції Ради Європи про права людини та біомедицину», Закону України «Основи законодавства України про охорону здоров'я» зі змінами, Наказів Міністерства охорони здоров'я України, Етичного кодексу лікаря України та Етичного кодексу вченого України, чинного законодавства.

\section{Результати та їх обговорення}

При порівнянні груп за віком і статтю статистично значимих відмінностей не виявлено.

При порівнянні показників моторно-когнітивного статусу за NIHSS і ADL BI, mRS, BBS, MMSE, MoCa, на 3-7 день після перенесеного мозкового півкульового ішемічного інсульту між контрольною групою (пацієнти контрольної групи за NIHSS і ADL BI не оцінювалися) та досліджуваними групами 1 і 2 за всіма шкалами виявлено статистично значимі міжгрупові відмінності ( $p_{0-1}, p_{0-2}$ відповідно), тоді як у цей час між групами 1 і 2 за показниками всіх шкал статистично значима різниця ( $\left.\mathrm{p}_{1-2}\right)$ була відсутня:

NIHSS - 9,83 (95\% ДI = 9,2 - 10,46) балів у групі 1 проти 9,55 (95\% ДІ = 8,91 - 10,18) балів у групі 2 $\left(p_{1-2}=0,51\right)$;

ADL BI - 46,03 (95\% ДI = 39,65 - 52,42) балів у групі 1 проти 47,1 (95\% ДІ = 40,85 - 53,34) балів у групi $2\left(p_{1-2}=0,49\right)$;

$\mathrm{mRS}-0,13(95 \%$ ДI $=0,01-0,26)$ бали в КГ проти $3,28(95 \%$ ДІ $=3,04-3,51)$ балів у групі $1\left(\mathrm{p}_{0}\right.$ $\left.{ }_{1}<0,0001\right)$ та $3,26(95 \%$ ДI $=3,08-3,44)$ балів у групі 2 ( $\mathrm{p}_{0-2}<0,0001 ; \mathrm{p}_{1-2}=0,78$ відповідно);

BBS - 55,4 (95\% ДI = 54,92 - 55,88) бали в КГ проти $23,83(95 \%$ ДІ = 20,48 - 21,18) балів у групі 1 (ро$\left.{ }_{1}<0,0001\right)$ та $26,9(95 \%$ ДІ = 23,46 - 30,34) балів у групі 2 ( $\mathrm{p}_{0-2}<0,0001 ; \mathrm{p}_{1-2}=0,24$ відповідно);

MMSE - 28,3 (95\% ДІ = 27,96 - 28,64) бали в КГ проти $22,24(95 \%$ ДІ $=21,13-23,36)$ балів у групі 1 (ро$\left.{ }_{1}<0,0001\right)$ та $22,68(95 \%$ ДІ $=21,75-23,61)$ балів у групі 2 ( $\mathrm{p}_{0-2}<0,0001 ; \mathrm{p}_{1-2}=0,74$ відповідно);

МoCa - 27,57 (95\% ДІ = 27,19-27,94) бали в КГ проти 18,86 (95\% ДІ = 17,25 - 20,48) бали у групі 1 $\left(p_{0-1}<0,0001\right)$ та $19,45(95 \%$ ДI $=18,04-20,87)$ балів у групі 2 ( $p_{0-2}<0,0001 ; p_{1-2}=0,55$ відповідно).

При огляді на 30-й день після МПІІ за показниками досліджуваних шкал статистично значимої різниці між першою та другою групами також не спостерігалося, тоді як при оцінці на 90-й день у групі 2 спостерігалося достовірно краще відновлення функцій за всіма «моторними» шкалами та за МоСа порівняно з групою 1: NIHSS - 4,61 (95\% ДІ = 4,32 - 4,91) бали проти 5,38 $(95 \%$ ДІ $=4,95-5,81)$ балів відповідно $(p=0,012) ; A D L$ $\mathrm{BI}-82,74(95 \%$ ДІ = 81,47 - 84,01) бали проти 75,86 $(95 \%$ ДІ = 73,38 - 78,34) балів відповідно ( $p<0,0001)$; $\mathrm{mRS}-1,48(95 \%$ ДІ $=1,28-1,68)$ бали проти 2,07 $(95 \%$ ДІ = 1,83 - 2,31) балів відповідно ( $p=0,0008)$; BBS - 39,26 (95\% ДІ = 38,25 - 40,27) бали проти 36,14 $(95 \%$ ДІ $=35,05-37,22)$ балів відповідно ( $p=0,0002)$; MMSE - 25,48 (95\% ДІ = 25,0 - 25,97) бали проти 24,9 $(95 \%$ ДІ $=24,31-25,48)$ балів відповідно ( $p=0,132)$; МоCa - 23,71 (95\% ДІ = 23,0 - 24,42) бали проти 22,45 $(95 \%$ ДІ $=21,57-23,33)$ балів відповідно $(p=0,04)$.

При оцінці пацієнтів за досліджуваними шкалами на 180-й день отримано наступні значення в групі 2 проти групи 1: NIHSS - 3,65 (95\% ДІ = 3,26 - 4,03) бали проти 4,24 (95\% ДІ = 3,73 - 4,75) балів відповідно $(p=0,113) ;$ ADL BI - 85,48 (95\% ДІ = 84,02 - 86,95) бали проти 82,07 (95\% ДІ = 79,76 - 84,38) балів відповідно $(p=0,067) ; m R S-1,45(95 \%$ ДІ = 1,27 - 1,63) бали проти 1,93 (95\% ДІ = 1,66 - 2,2) балів відповідно $(p=0,011)$; BВS - 43,87 (95\% ДІ = 42,17 - 45,58) бали проти 40,93 (95\% ДІ = 38,76 - 43,1) балів відповідно $(\mathrm{p}=0,046)$; MMSE - 26,29 (95\% ДІ = 25,67 - 26,91) бали проти 25,34 (95\% ДІ = 24,72 - 25,97) балів відповідно $(p=0,032)$; МоСа $-25,32$ (95\% ДІ = 24,82 - 25,82) бали 
проти 24,07 (95\% ДІ = 23,21 - 24,92) балів відповідно $(p=0,016)$.

Результати тестування на 90-й день та 180-й день після гострої цереброваскулярної катастрофи демонструють достовірно краще відновлення порушених моторно-когнітивних функцій після МПII під впливом комплексних терапевтично-реабілітаційних заходів із

застосуванням методів активної реабілітації спільно 3 препаратом а-гліцерилфосфорилхоліну.

При оцінці динамічних змін усередині груп встановлено статистично значимі зміни середніх сумарних показників за досліджуваними шкалами у групах 1 і 2 в динаміці спостереження. Відповідні дані на 3-7 день та 180-й день після МПІІ представлені в табл. 1.

Таблиця 1

Порівняння середніх сумарних показників досліджуваних шкал усередині груп 1 і 2 до та через 6 міс. після лікування МПІІ

\begin{tabular}{|c|c|c|c|c|}
\hline \multirow[b]{2}{*}{ Група } & \multirow[b]{2}{*}{ Показник } & \multicolumn{2}{|c|}{ Період спостереження } & \multirow{2}{*}{$\begin{array}{l}\text { Достовірність } \\
\text { (Wilcoxon) }\end{array}$} \\
\hline & & $\begin{array}{c}\text { 3-7 день } \\
(\mathrm{M} \pm \mathrm{m})\end{array}$ & $\begin{array}{c}\text { 180-й день } \\
(\mathrm{M} \pm \mathrm{m})\end{array}$ & \\
\hline \multirow{6}{*}{$\begin{array}{c}\text { Група } 1 \\
(\mathrm{n}=29)\end{array}$} & NIHSS & $9,83 \pm 0,32$ & $4,24 \pm 0,26$ & \multirow{6}{*}{$<0,0001$} \\
\hline & $\mathrm{ADL} \mathrm{BI}$ & $46,03 \pm 3,26$ & $82,07 \pm 1,18$ & \\
\hline & $\mathrm{mRS}$ & $3,28 \pm 0,12$ & $1,93 \pm 0,14$ & \\
\hline & BBS & $23,83 \pm 1,71$ & $40,93 \pm 1,11$ & \\
\hline & MMSE & $22,24 \pm 0,57$ & $25,34 \pm 0,32$ & \\
\hline & $\mathrm{MoCa}$ & $18,86 \pm 0,82$ & $24,07 \pm 0,44$ & \\
\hline \multirow{6}{*}{$\begin{array}{c}\text { Група } 2 \\
(n=31)\end{array}$} & NIHSS & $9,55 \pm 0,32$ & $3,65 \pm 0,19$ & \multirow{6}{*}{$<0,0001$} \\
\hline & ADL BI & $47,1 \pm 3,19$ & $85,48 \pm 0,75$ & \\
\hline & $\mathrm{mRS}$ & $3,26 \pm 0,09$ & $1,45 \pm 0,09$ & \\
\hline & BBS & $26,9 \pm 1,76$ & $43,87 \pm 0,87$ & \\
\hline & MMSE & $22,68 \pm 0,47$ & $26,29 \pm 0,32$ & \\
\hline & $\mathrm{MoCa}$ & $19,45 \pm 0,72$ & $25,32 \pm 0,26$ & \\
\hline
\end{tabular}

Динаміку відновлення функціональних порушень після МПІІ у пацієнтів досліджуваних груп у різні терміни спостереження відображено на рисунках 1-6.

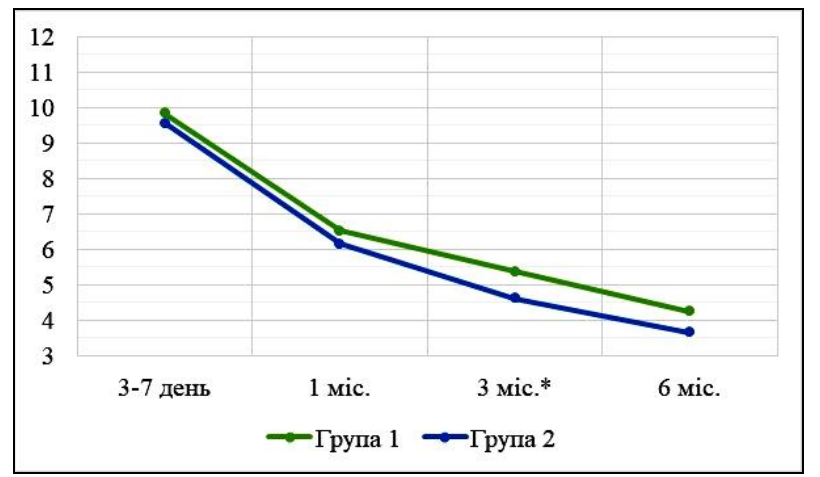

Puc. 1. Динаміка середніх значень показників за шкалою NIHSS у пацієнтів груп 1 і 2 у різні терміни спостереження. Примітка: * - доведена різниця між показниками груп $(p<0,05)$

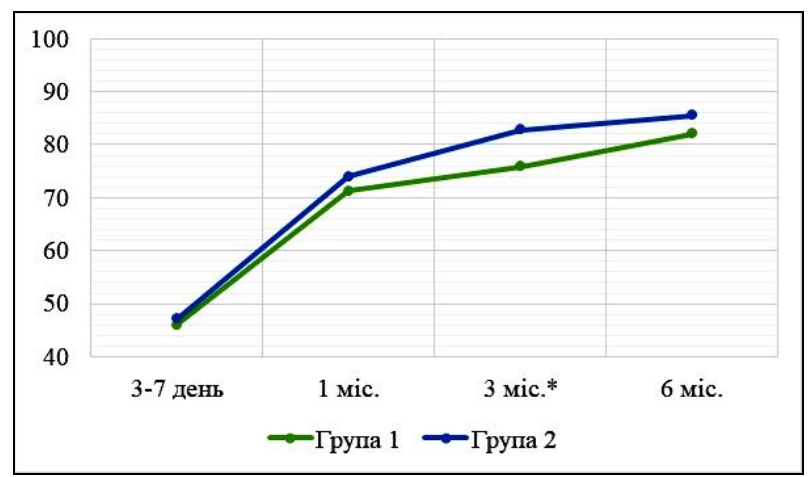

Puc. 2. Динаміка середніх значень показників за шкалою ADL ВІ у пацієнтів груп 1 і 2 у різні терміни спостереження. Примітка: * - доведена різниця між показниками груп $(p<0,05)$

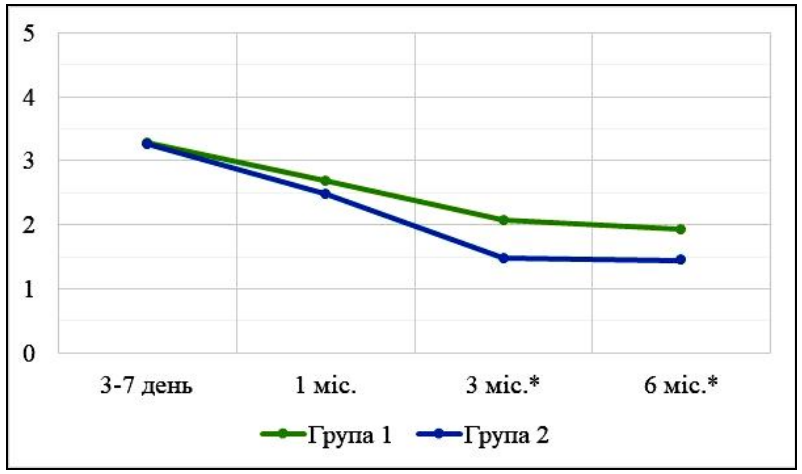

Puc. 3. Динаміка середніх значень показників за шкалою mRS у пацієнтів груп 1 і 2 у різні терміни спостереження.

Примітка: * - доведена різниця між показниками груп $(p<0,05)$

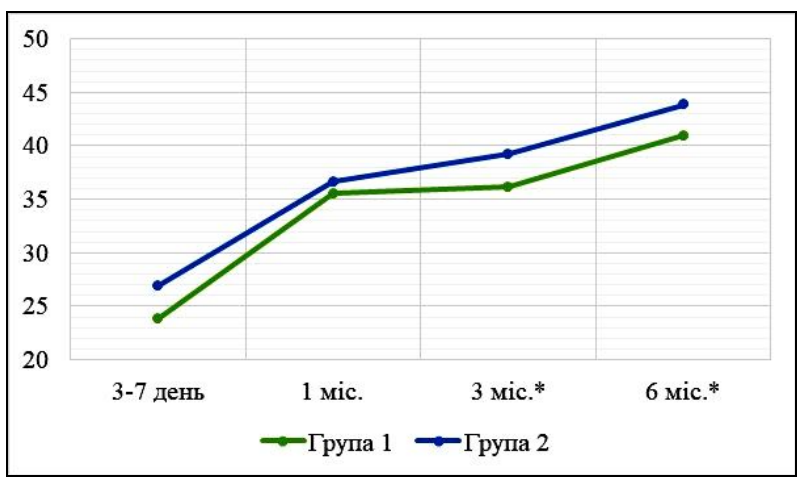

Pис. 4. Динаміка середніх значень показників за шкалою BBS у пацієнтів груп 1 і 2 у різні терміни спостереження. Примітка: * - доведена різниця між показниками груп $(p<0,05)$ 
ToM 25, N 3-4 2021 p.

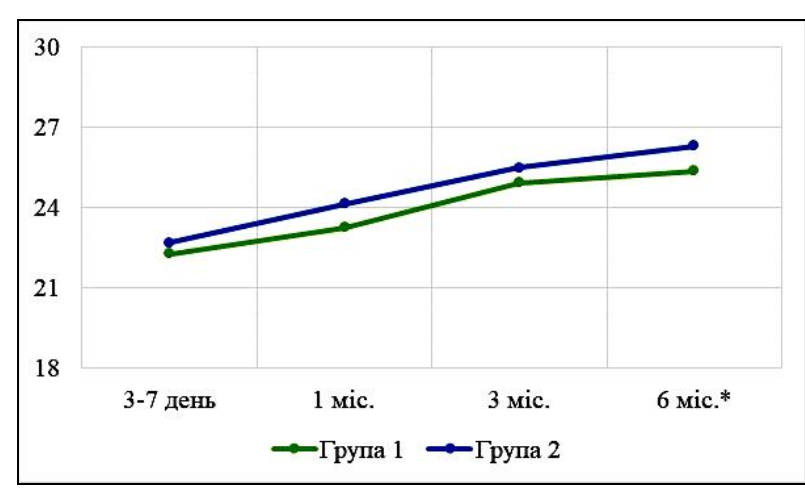

Puc. 5. Динаміка середніх значень показників за шкалою MMSE у пацієнтів груп 1 i 2 у різні терміни спостереження. Примітка: * - доведена різниця між показниками груп $(p<0,05)$

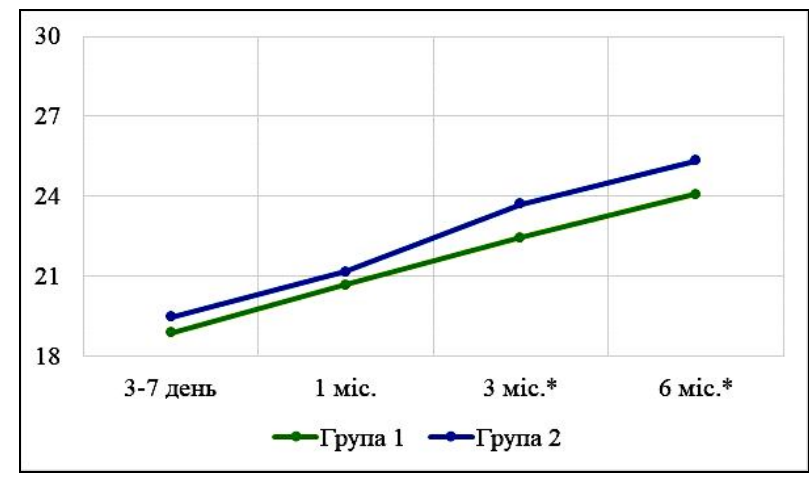

Puc. 6. Динаміка середніх значень показників за шкалою МоСа у пацієнтів груп 1 і 2 у різні терміни спостереження.

Примітка: * - доведена різниця між показниками груп $(p<0,05)$

3 метою уточнення динаміки змін моторнокогнітивних порушень у хворих на мозковий півкульовий ішемічний інсульт у досліджуваних групах був проведений аналіз із визначенням приросту/спаду середніх значень показників за скринінговими шкалами на 30-й, 90-й та на 180-й день відносно їх початкових значень після церебральної катастрофи. Так, порівняно з початковими середні значення змінилися наступним чином:

за NIHSS на 30-й день показник зменшився у групі 1 на 33,68\%, у групі 2 - на 35,47\%, на 90-й день у групі 1 - на 45,26\%, у групі 2 - на 51,69\%, на $180-и ̆$ день у групі 1 - на 56,84\%, у групі 2 - на $61,82 \%$;

- 3 a ADL BI на 30-й день показник зріс у групі 1 на $54,68 \%$, у групі 2 - на $57,19 \%$, на 90-й день у групі 1 - на 64,79\%, у групі 2 - на 75,68\%, на 180-й день у групі 1 - на 78,28\%, у групі 2 - на $81,51 \%$;

за mRS на 30-й день показник зменшився у групі 1 на 17,89\%, у групі 2 - на 23,76\%, на 90-й день у групі 1 - на $36,84 \%$, у групі 2 - на $54,56 \%$, на $180-и ̆$ день у групі 1 - на 41,05\%, у групі 2 - на 55,45\%;

за BBS на 30-й день показник зріс у групі 1 на $49,2 \%$, у групі 2 - на 36,21\%, на 90-й день у групі 1 на $51,66 \%$, у групі 2 - на 45,92\%, на 180-й день у групі 1 - на $71,78 \%$, у групі 2 - на $63,07 \%$;

- за MMSE на 30-й день показник зріс у групі 1 на

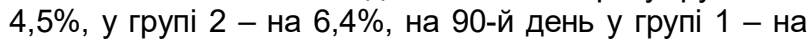
$11,94 \%$, у групі 2 - на 12,38\%, на 180-й день у групі 1 - на $13,95 \%$, у групі 2 - на $15,93 \%$;

- за МоСа на 30-й день показник зріс у групі 1 на $9,51 \%$, у групі 2 - на 8,79\%, на 90-й день у групі 1 - на $19,01 \%$, у групі 2 - на $21,89 \%$, на 180-й день у групі 1 - на $27,61 \%$, у групі 2 - на 30,18\%.

Враховуючи універсальність шкали $\mathrm{mRS}$, що позитивно вирізняється зрозумілою демонстрацією практично повного спектру обмежень активності в пацієнтів після інсульту, для відображення інтегрального показника їх функціональної спроможності, в ході роботи було проведено аналіз динаміки змін $(\Delta)$ середніх значень показників за шкалою $\mathrm{mRS}$ у досліджуваних групах у різні періоди спостереження після МПI. Відповідні дані представлені в табл. 2.

Таблиця 2

Порівняння динаміки змін ( $\Delta$ ) середніх значень показників за шкалою mRS у групах 1 і 2 на 30-й, 90-й та 180-й дні після МПII порівняно з їх початковими значеннями, бали

\begin{tabular}{|c|c|c|c|}
\hline & Група 1 & Група 2 & Mann-Whitney U-test \\
\hline$\Delta \mathrm{mRS}_{\mathrm{V} 2-\mathrm{v} 1}$ & $0,59 \pm 0,14$ & $0,77 \pm 0,11$ & $p=0,266$ \\
\hline$\Delta \mathrm{mRS}_{\mathrm{V} 3-\mathrm{V} 1}$ & $1,21 \pm 0,17$ & $1,77 \pm 0,1$ & $p=0,006$ \\
\hline$\Delta \mathrm{mRS}_{\mathrm{V} 4-\mathrm{V} 1}$ & $1,34 \pm 0,18$ & $1,81 \pm 0,1$ & $p=0,041$ \\
\hline
\end{tabular}

Примітка: $\triangle$ mRS v2-v1 - зміна показника на 30-й день порівняно з початковим значенням,

$\Delta m R S$ v3-v1 - зміна показника на 90-й день порівняно з початковим значенням,

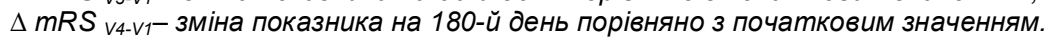

Додатково був проведений кореляційний аналіз між відповідними діагностичними параметрами в до-

сліджуваних групах у різні періоди спостереження. Відповідні дані представлені в табл. 3.

Таблиця 3

Кореляційні зв'язки між середніми сумарними значеннями досліджуваних показників у різні періоди спостереження після МПII в групах 1 і 2

\begin{tabular}{|c|c|c|c|c|c|c|}
\hline \multirow{3}{*}{ Показники } & \multicolumn{6}{|c|}{ Коефіцієнт кореляції, R } \\
\hline & \multicolumn{3}{|c|}{ Група 1} & \multicolumn{3}{|c|}{ Група 2} \\
\hline & 1 мic. & 3 мic. & 6 мiс. & 1 мiс. & 3 мic. & 6 мic. \\
\hline NIHSS - ADL BI & $-0,444^{*}$ & $-0,566^{\star *}$ & $-0,654^{* *}$ & $-0,571^{* *}$ & $-0,685^{* *}$ & $-0,456^{\star *}$ \\
\hline NIHSS - mRS & $+0,49^{* *}$ & $+0,651^{* *}$ & $+0,64^{\star *}$ & $+0,49^{* *}$ & $+0,75^{\star *}$ & $+0,681^{* *}$ \\
\hline NIHSS - BBS & $-0,359$ & $-0,564^{* *}$ & $-0,599^{\star *}$ & $-0,423^{*}$ & $-0,399^{*}$ & $-0,459^{\star *}$ \\
\hline ADL BI - mRS & $-0,553^{* *}$ & $-0,787^{* *}$ & $-0,782^{\star *}$ & $-0,296$ & $-0,828^{* *}$ & $-0,486^{* *}$ \\
\hline ADL BI - BBS & $+0,752^{* *}$ & $+0,505^{\star *}$ & $+0,853^{* *}$ & $+0,678^{\star *}$ & $+0,815^{\star *}$ & $+0,637^{* *}$ \\
\hline $\mathrm{mRS}-\mathrm{BBS}$ & $-0,545^{\star *}$ & $-0,441^{*}$ & $-0,743^{\star *}$ & $-0,34$ & $-0,644^{\star *}$ & $-0,339$ \\
\hline MoCa - MMSE & $+0,812^{* *}$ & $+0,469^{*}$ & $+0,67^{* *}$ & $+0,773^{\star *}$ & $+0,626^{* *}$ & $+0,745^{\star *}$ \\
\hline
\end{tabular}

Примітка: * - кореляція значима на рівні $p<0,05$, ** - кореляція значима на рівні $p<0,01$. 
Отримані результати дослідження демонструють перевагу комбінації методів активної реабілітації та використання фармакологічного препарату $\alpha$ гліцерилфосфорилхоліну, оскільки застосування останнього в схемі комплексного лікування пацієнтів у гострому та відновному періодах мозкового півкульового ішемічного інсульту дозволяє підвищити ефективність функціонального відновлення пацієнтів, що ймовірно зв'язано зі здатністю а-GPC позитивно впливати на властивості клітинних мембран нервової системи, міжнейрональну передачу, процеси нейропластичності та вказує на доцільність і ефрективність його застосування для зменшення моторнокогнітивного дефіциту після ішемічного інсульту.

\section{Висновки}

Застосування препарату а-гліцерилфоссрорилхоліну в схемі комплексного лікування пацієнтів у гострому та відновному періодах МПII $€$ обґрунтованим та сприяє пришвидшенню й підвищенню ефективності функціонального відновлення після гострої церебральної катастрофи. Отримані результати можуть знайти практичне застосування в підвищенні ефективності терапевтично-реабілітаційних програм для пацієнтів після перенесеного мозкового півкульового ішемічного інсульту для зменшення постінсультного дефріциту.

\section{Перспективи подальших досліджень}

Проведення досліджень з оптимізації терапевтично-реабілітаційних заходів у пацієнтів із мозковим півкульовим ішемічним інсультом із урахуванням особливостей моторно-нейрокогнітивного дефіциту.

\section{Література}

1. Virani SS, Alonso A, Benjamin EJ, Bittencourt MS, Callaway CW Carson AP et al. Heart Disease and Stroke Statistics-2020 Update: A Report From the American Heart Association. Circulation. 2020; 141(9):e139-e596. DOI: $10.1161 / C I R .0000000000000757$

2. Norrving B, Barrick J, Davalos A, Dichgans M, Cordonnier C, Guekht A, et al. Action Plan for Stroke in Europe 20182030. European Stroke Journal. 2018; 3(4):309-336. DOI: $10.1177 / 2396987318808719$

3. Ministerstvo okhorony zdorovia Ukrainy. Unifikovanyi klinichnyi protokol medychnoi dopomohy «lshemichnyi insult (ekstrena, pervynna, vtorynna (spetsializovana) medychnadopomoha, medychnareabilitatsiia) [Internet]. 2012. Nakaz №602. 2012 serpen 03. Available from: https://dec.gov.ua/wp-

content/uploads/images/dodatki/2012 602/2012 602dod4 ykpmd.pdf. [Ukrainian]

4. Polishchuk ME, Shchehlov DV, Goncharuk OM, Mamonova MYu, Konotopchyk SV. Suchasnyi stan ta perspektyvy likuvannia insultiv $\vee$ Ukraini. Endovaskuliarna neirorenthenokhirurhiia. 2017;4(22):14-22. DOI 10.26683/2304-9359-2017-4(22)-14-22. [Ukrainian]

5. Pushko OO, Lytvynenko NV. Peculiarities of neurocognitive status of patients in the acute ischemic stroke phase of different hemispheric localization. World of Medicine and Biology. 2020; 2(72):99-103. DOI 10.26724/20798334-2020-2-72-99-103

6. Katan M, Luft A. Global burden of stroke. Seminars in Neurology. 2018; 38(02):208-11. DOI: 10.1055/s-00381649503

7. Onishchenko LS, Gaikova ON, Yanishevskii SN. Changes at the focus of experimental ischemic stroke treated with neuroprotective agents. Neuroscience and behavioral physiology. 2008; 38(1):49-54. DOI: 10.1007/s11055-0080007-1

8. Powers WJ, Rabinstein AA, Ackerson T, Adeoye OM, Bambakidis NC, Becker K, et al. Guidelines for the early management of patients with acute ischemic stroke: 2019 update to the 2018 guidelines for the early management of acute ischemic stroke a guideline for healthcare professionals from the American Heart Association/American Stroke Association. Stroke. 2019; 50:e344-e418. DOI: 10.1161/STR.0000000000000211

9. European Physical and Rehabilitation Medicine Bodies Alliance. White Book on Physical and Rehabilitation Medicine in Europe. European Journal of Physical and Rehabilitation Medicine. 2018; 54(2):125321. DOI: $10.23736 /$ S1973-9087.18.05143-2

10. Mishchenko VN. Medotilin $v$ lechenii postinsultnykh kognitivnykh narusheniy. Mezhdunarodnyy nevrologicheskiy zhurnal. 2017; 3(89):45-51. DOI: 10.22141/2224-0713.3.89.2017.104242 [Russian]

11. Marcus L, Soileau J, Judge L, Bellar D. Evaluation of the effects of two doses of alpha glycerylphosphorylcholine on physical and psychomotor performance. Journal of the International Society of Sports Nutrition. 2017; 14:39. DOI: 10.1186/s12970-017-0196-5

12. Tayebati SK, Marucci G, Santinelli C, Buccioni M, Amenta F. Choline-Containing Phospholipids: Structure-Activity Relationships Versus Therapeutic Applications. Current Medicinal Chemistry. 2015; 22(38):4328-4340. DOI: $10.2174 / 0929867322666151029104152$

13. Gallelli L. Choline alphoscerate pharmacology and its role in the treatment of cognitive impairment related to neurological disorders. Functional Neurology. 2011; 26(S1):1-7.

14. Rachin AP. Vygovskaya SN. Nuvakhova MB. Doroginina $\mathrm{AYu}$. Khronicheskaya ishemiya golovnogo mozga - ot pravilnoy diagnostiki $\mathrm{k}$ adekvatnoy terapii. Russkiy meditsinskiy zhurnal. 2015; 12:694-698. [Russian]

15. Chernii TV, Fokina DO, Chernii VI. Kompleksne likuvannia khvorykh z khronichnoiu ishemiieiu mozku. tsilespriamovana korektsiia kohnityvnykh porushen ta vidnovlennia rukhovykh funktsii pislia perenesenoho mozkovoho insultu. Klinichna ta profilaktychna medytsyna. 2020; 4(14):33-43. DOI: 10.31612/26164868.4(14).2020.02 [Ukrainian]

16. Gage M, Phillips K, Noh B, Yoon T. Effect of an AlphaGPC Supplement on Physical Performance in Division 2 Football Players. Medicine \& Science in Sports \& Exercise. 2017; 49(5S):942. DOI: 10.1249/01.mss.0000519566.89731.74

17. Nasonova TI, Kolosova TV, Slobodyn TM, Klymenko OV, Kurochkin IV, Riabychenko TM, ta in. Porushennia pamiati y uvahy $v$ patsiientiv serednoho viku: diahnostyka y likuvannia. Mizhnarodnyi nevrolohichnyi zhurnal. 2018; 2(96):19-25. DOI: 10.22141/2224-0713.2.96.2018.130478 [Ukrainian]

18. Bellar D, LeBlanc N, Campbell B. The effect of 6 days of alpha glycerylphosphorylcholine on isometric strength. Journal of the International Society of Sports Nutrition. 2015; 12:42. DOI 10.1186/s12970-015-0103-x

19. Mishchenko TS. Mishchenko VN. Lapshina IA. Gliatilin v lechenii postinsultnykh bolnykh. Mezhdunarodnyy nevrologicheskiy zhurnal. 2016; 4(82):25-31 [Russian]

20. Traini E, Bramanti V, Amenta F. Choline alphoscerate (alpha-glyceryl-phosphoryl-choline) an old cholinecontaining phospholipid with a still interesting profile as cognition enhancing agent. Current Alzheimer research. 2013; 10(10):1070-1079 DOI: $10.2174 / 15672050113106660173$

Матеріал надійшов до редакції 27.05.2021 